\title{
Recurrent Cervical Squamous Cell Carcinoma, Not Otherwise Specified
}

National Cancer Institute

\section{Source}

National Cancer Institute. Recurrent Cervical Squamous Cell Carcinoma, Not Otherwise

Specified. NCI Thesaurus. Code C136649.

The reemergence of cervical squamous cell carcinoma after a period of remission. 